\title{
9 In search of a middle ground
}

\author{
Addressing cultural and religious \\ influences on the criminalization \\ of homosexuality in Nigeria
}

\author{
Adetoun T Adebanjo
}

\section{Introduction}

Nigeria is a largely homophobic nation. Cultural and religious beliefs have a major role to play in this stance. The disposition to same-sex relationships is rooted in the belief that same-sex relationships are alien to African culture, and to Christianity and Islam, the two major religions practised in Nigeria.

Prior to the introduction of the Same Sex Marriage (Prohibition) Act 2013, the Criminal Code Act (applicable in the South), ${ }^{1}$ the Penal Code Act (applicable in the North) and Shariah Law (applicable in 12 Northern states) had already criminalized homosexuality. ${ }^{2}$

Homosexuality is a felony under section 214 of the Criminal Code and is punishable by up to 14 years imprisonment. The Penal Code has adopted an even stricter stance. In terms of section 284, an offender is liable to a fine and imprisonment of up to 14 years, while section 405(2)(e) defines a vagabond to include 'any male person who dresses or is attired in the fashion of a woman in a public place or who practices sodomy as a means of livelihood', and an offender could be liable to two years imprisonment and a fine.

Shari'a Law is also notorious for prohibiting same-sex relationships. ${ }^{3}$ The provisions vary from state to state. Punishments range from receiving hundred lashes of the cane to being stoned to death. For instance, in Kano and Zamfara, ${ }^{4}$ unmarried offenders receive hundred lashes of the cane and one-year jail terms, while for married offenders, the law prescribes stoning to death. In Bauchi state, the law prescribes the death sentence 'or any other means decided by the state'. ${ }^{5}$ In Kebbi State, all offenders are to be stoned to death. ${ }^{6}$

The combination of all these laws was already lethal for gay people in Nigeria. The 2013 Act was therefore unnecessary. It merely goes further to specifically ban same-sex marriages, and impose liabilities on anyone seen as aiding and abetting these unions. However, since no court in Nigeria would have solemnized a marriage involving gay people, the Act is practically redundant.

This chapter will argue that Nigeria's anti-gay laws violate several fundamental human rights principles and must therefore be addressed. The chapter will suggest amendments to Nigeria's Constitution to better protect sexual minorities. Drawing on specific examples of victimization experienced by gay people in Nigeria, the chapter will show the urgency in addressing the current

DOI: $10.4324 / 9781003175049-9$ 
situation. It will draw on the inspirational story of an Australian Catholic priest who championed the fight to end the violence against gay people in Australia, to show that religious or cultural beliefs should not preclude tolerance and respect for sexual minorities.

\section{Cultural and religious influences on same-sex relationships in Nigeria}

In Nigerian culture, religion and morality are often so intertwined that separating them can prove difficult. For example, the two major religions i.e. Christianity and Islam have expectations of high morality and modesty on their followers. Homosexuality is believed to be against African culture and morality. ${ }^{7}$ In a 2013 survey by the Pew Research Centre, ninety-eight percent of Nigerians were polled to be against homosexuality as they believed it was incompatible with cultural and moral values. ${ }^{8}$ Mujuzi believes this mindset stems in part from the belief that everyone was born straight, and that homosexuality is a practice to which people are lured. ${ }^{9}$

The above survey report notes the existence of a strong relationship between a country's religiosity and opinions about homosexuality, with usually far less acceptance being recorded in countries where religion was central to people's lives, and conversely more widespread acceptance of homosexuality in countries where religion was less central to people's lives. ${ }^{10}$ Hence, religious bodies are vocal in the attack on homosexuality in Nigeria. ${ }^{11}$ Former President Olusegun Obasanjo had said of homosexuality during his presidency 'Such a tendency is clearly un-Biblical, unnatural and definitely un-African' and was therefore 'totally unacceptable'. ${ }^{12}$ Statements like these have the effect of endorsing criminalization and abuse.

Understanding sexuality as an innate thing in the individual will aid a better understanding of homosexuality and encourage tolerance for gay people. In the words of Adebanjo, taking time to understand gay people will sow the seeds necessary for change..$^{13}$ It is therefore important to correct the above mindset. In a society such as Nigeria where the law, religion, culture and morality are so deeply intertwined, it may be necessary to pull at the layers of each of these components, to unravel the way society's mind works. Baxter postulates that in determining how the law affects morality, it is expedient to ask if we have a moral obligation to follow the law, and conversely that in determining how morality affects the law, the question then becomes how relevant morality is in fixing the law. ${ }^{14}$

Nigerian culture is such that seeks a spiritual angle to explain any sexual orientation which does not conform to the norm. Some ethnicities have been known to perform 'cleansing rituals' on homosexuals, while religious houses also perform exorcisms to rid people of 'the gay spirit'. ${ }^{15}$

Nigeria is not alone in its criminalization of same-sex relationships. Many African countries have held on to the belief that homosexuality is incompatible with African culture and morality. Uganda introduced the Uganda 


\section{Adetoun T Adebanjo}

Anti-Homosexuality Act in 2014, ${ }^{16}$ but it was declared invalid by the Constitutional Court of Uganda in August of the same year, on the basis that the required quorum was not formed before the law was passed. ${ }^{17}$ Other African countries which criminalized same-sex relationships include Malawi ${ }^{18}$ and Kenya ${ }^{19}$ to mention just a few. South Africa therefore stands out for decriminalizing same-sex relationships on a continent where same-sex relationships are being demonized and vilified. ${ }^{20}$

\section{The Same Sex Marriage (Prohibition) Act 2013}

The Same Sex Marriage (Prohibition) Act 2013 is a harsh law which stifles the rights of Nigeria's gay community. The UN High Commissioner for Human Rights rightly sums up the Act in the following words: ${ }^{21}$

Rarely have I seen a piece of legislation that in so few paragraphs directly violates so many basic, universal human rights. Rights to privacy and nondiscrimination, rights to freedom of expression, association and assembly, rights to freedom from arbitrary arrest and detention: this law undermines all of them. In addition, the law risks reinforcing existing prejudices towards members of the LGBT community, and may provoke an upsurge in violence and discrimination.

Comprising eight sections, the Act goes for the jugular. To clear any ambiguity, the Act defines marriage and sets out parties to a valid marriage in Nigeria thus "'marriage" means a legal union entered into between persons of opposite sex in accordance with the Marriage Act, Islamic Law or Customary Law'. ${ }^{22}$ As pointed out by Barnard and De Vos, refusal to let go of this ingrained idea could be borne out of the thought that to change the definition of marriage will be unnatural or even impossible. ${ }^{23}$

Section 1 prohibits marriages or civil unions between persons of the same sex in Nigeria irrespective of the jurisdiction they were contracted in. Under the section, such unions were not entitled to benefits accruing to valid marriages. ${ }^{24}$ The impact of this section is that valid same-sex marriages/unions of foreign nationals were invalid in Nigeria. Likewise, same-sex marriages of Nigerians conducted in foreign jurisdictions which recognize same-sex unions would not be recognized in Nigeria. This provision creates problems for gay foreigners living in Nigeria who have contracted valid unions elsewhere. Section 5(1) prescribes a term of 14 years imprisonment for offenders.

Section 2 prohibits places of worship from solemnizing same-sex unions. No certificate issued in respect of a same-sex marriage/union will be valid in Nigeria. ${ }^{25}$ Section 3 goes ahead to emphasize that only a marriage contracted between a man and a woman shall be valid in Nigeria.

The Act arbitrarily bans the registration of gay clubs and associations, ${ }^{26}$ and attaches a ten-year jail term for those found to be operating or participating in such. ${ }^{27}$ It also seeks to punish persons who administer or witness the solemnization of same-sex unions, and prescribes a ten-year jail-term for offenders. This 
effectively means loved ones of the couple could be penalized just for showing support.

Public shows of affection between same-sex couples are prohibited, and offenders are liable to ten years imprisonment. ${ }^{28}$ The use of the words 'directly or indirectly' under section 5(2) makes the interpretation of what constitutes 'public show' subjective and therefore difficult. For instance, two long-lost friends who are genuinely happy to see each other and expressing that happiness can be misconstrued to be 'directly or indirectly' making a public show of a homosexual relationship.

While the Same Sex Marriage (Prohibition) Act has been mostly welcomed in Nigeria, it has been greeted with disdain in the international community, with several countries calling for its withdrawal or review. ${ }^{29}$ Noting the negative impact of the passage of the Act, Dorothy Aken'Ova, executive director of the International Centre for Reproductive Health and Sexual Rights observed that the Act had reawakened interest in communities to rid the country of gay people and gay tendencies, and had driven many gay people 'into the closet'. ${ }^{30}$ Arrests of suspected gay people multiplied, with rights activists having to go underground and several gay people seeking asylum in foreign countries. ${ }^{31}$

Juxtaposed with the South African regime, inadequacies in the Nigerian system become glaring. Not only has South Africa decriminalized homosexuality, it has actively tried to protect the rights of its gay population. In addition to expressly legislating to protect their fundamental rights, the introduction of the Civil Union Act is another step towards this aim. It must be pointed out however that even though the South African Civil Union Act confers full marriage rights on qualifying same-sex couples, it has been criticized for a number of reasons, a major one being that it is perceived to have unnecessarily complicated South Africa's family law system by favouring heterosexual couples to marry under both the Marriage Act and the Civil Union Act, but presenting same-sex couples with only the option of a civil union under the Civil Union Act. ${ }^{32}$

Nigeria needs to urgently review its anti-gay law and decriminalize samesex relationships. This would be a good place to start showing tolerance and acceptance of its gay population and to recognize their struggles.

\section{The non-conformity of Nigeria's anti-gay stance with Human Rights principles.}

The protection of the right of sexual minorities has been of paramount interest for international and regional bodies in recent times. The rationale for this has been eloquently set out by the UN thus:

The case for extending the same rights to Lesbian, Gay, Bisexual and transgender (LGBT) persons as those enjoyed by everyone else is neither radical nor complicated. It rests on two fundamental principles that underpin international human rights law: equality and non-discrimination ${ }^{33}$ 
The UN Human Rights Council adopted resolution 17/19, ${ }^{34}$ which was the first of its kind from the UN on issues pertaining to human rights, sexual orientation and gender identity. It mandated the UN High Commissioner for Human Rights to commission a study documenting discriminatory law and practices and acts of violence against people based on sexual orientation and gender identity, and how international human rights law could aid in putting an end to violence and other HR violations in this regard. In September 2016, the Human Rights Council adopted resolution 32/2, which also sought, among other things, to protect sexual minorities from violence and discrimination, and to appoint an independent expert on Sexual Orientation and Gender Identity. This shows a commitment at the international level to enforce the protection of the rights of sexual minorities. Also, General Comments such as General Comment No 22 of 2016 which will be discussed in further detail below support this assertion. Attempts at regional level will also be examined further into the chapter.

As a State Party to numerous international human rights instruments, Nigeria has an obligation to comply and ensure compliance with the provisions of these instruments. The 2013 Act violates regional and international principles of fundamental human rights. these include the right to privacy, dignity, health, equality and non-discrimination, and the right to found a family.

\subsection{The right to privacy and family life}

Section 37 of the Nigerian Constitution guarantees the right to privacy and family life to all citizens. ${ }^{35}$ It provides 'The privacy of citizens, their homes, correspondence, telephone conversations and telegraphic communications is hereby guaranteed and protected'.

This right is guaranteed to every individual, and everyone should be able to enjoy it, irrespective of their sexual orientation. The Universal Declaration on Human Rights (Universal Declaration) ${ }^{36}$ and the International Covenant on Civil and Political Rights (ICCPR) also guarantee this right. ${ }^{37}$ Hence, the constant harassment of gay people and the compulsion to 'out' them is an invasion of this right.

The right to privacy has been argued successfully in cases such as Toonen $v$ Australia, ${ }^{38}$ and Norris $v$ Ireland. ${ }^{39}$ In the Toonen case, Nicholas Toonen was a homosexual living in Tasmania, Australia who challenged the criminalization of homosexuality in Tasmania. ${ }^{40}$ Toonen sent a communication to the Human Rights Committee of the ICCPR arguing that section 122(a) and (c) and section 123 of the Criminal Code of Tasmania which criminalized sexual contact between men violated his rights to privacy (Article 17 of the ICCPR) and non-discrimination (Article 26). ${ }^{41} \mathrm{He}$ lost his job during the pendency of the case.

Tasmania alleged that issues of morality should be regarded as being domestic decisions for individual governments, and that the provisions in question could help prevent the spread of HIV/AIDS. ${ }^{42}$ On the first issue, the 
Committee noted that there was danger in allowing such an argument to stand, because doing so would cause several laws which interfered with privacy to be withdrawn from the Committee's jurisdiction. ${ }^{43}$ It observed that the Australian government had on its part already conceded that criminalizing homosexuality had the opposite effect i.e. it caused gay people, who were most vulnerable to HIV/AIDS to go into hiding for fear of discrimination. ${ }^{44}$ The Committee also stated that Tasmania had failed to show any connection between continued criminalization of homosexuality and the effective control of the spread of $\mathrm{HIV} / \mathrm{AIDS}{ }^{45}$

Agreeing with Toonen, the Committee found sections 122 and 123 of Tasmania's Criminal Code to be in violation of the complainant's right to privacy. ${ }^{46}$ As a result of this case, Tasmania overhauled its discriminatory law while the whole country was forced to commence a review of its laws.

Similarly, in Norris $v$ Ireland which was brought before the European Court of Human Rights, the ECHR held that the Irish law criminalizing same-sex relationships between consenting adults was in violation of the right to private and family life guaranteed by Article 8 of the European Convention.

The right to family life is an offshoot of the right to privacy. It is guaranteed under Article 16 of the Universal Declaration and Article 23 of the ICCPR. In Valianatos and others $v$ Greece, ${ }^{47}$ the ECHR held that the legal recognition given to civil partnerships of different-sex couples to the exclusion of same sex couples was incompatible with Article 8 of the European Convention on Human Rights. The requirement is that the contracting parties must be of full age and must have given their free and full consent.

\subsection{The right to dignity}

Section 34 of the Nigerian Constitution recognizes the right to dignity for every individual. Section 34(1)(a) provides

Every individual is entitled to respect for the dignity of his person, and accordingly -

(a) No person shall be subject to torture or to inhuman or degrading treatment

The right to dignity is also preserved under the Universal Declaration (Articles 1 and 5), the ICCPR (Article 7) and the African Charter on Human and Peoples Rights (the Banjul Charter) (article 5).

Resolution 275 adopted at the 55th Ordinary Session of the African Commission in Luanda, Angola in 2014 specifically emphasizes the right to dignity for sexual minorities in Africa. ${ }^{48}$ Re-emphasizing the relevant provisions of the African Charter, ${ }^{49}$ the Commission condemned the spike in violence against sexual minorities, and called on State Parties to put an end to all acts of violence and abuse against sexual minorities, ensure proper investigation and prosecution of perpetrators of violence against them, and establishing 
working judicial procedures while providing an enabling environment for activists to work in.

The decisions of the African Commission in Curtis Doebbler $v$ Sudan ${ }^{50}$ and Abdel Hadi, Ali Radi and ors $v$ Repubic of Sudan ${ }^{51}$ are instructive on the right to dignity and freedom from torture, inhuman or degrading treatment as preserved under Article 5 of the Banjul Charter. The complainants in the Doebbler case were university students on a picnic in Buri, Khartoum. ${ }^{52}$ While the picnic was ongoing, the police and other security agents swooped in on them, alleging that their dressing and actions were in violation of 'public order' under Sudan's Criminal Law. ${ }^{53}$ In addition to paying fines, they were sentenced to between 25 and 40 lashes using a wire and plastic whip which leaves permanent scars. ${ }^{54}$ This whipping was carried out in public, with the women receiving theirs on their bare backs. ${ }^{55}$ At its 33rd Ordinary Session in Niamey, Niger in May 2003, the African Commission held that the provision on torture, cruel, inhuman or degrading treatment must be interpreted as widely as possible to encompass the widest array of physical and mental abuses possible. ${ }^{56}$ Finding Sudan to be in violation of Article 5, the Commission requested that the Sudanese government amend the offending provisions of its Criminal Law, that it abolish the penalty of lashes, and compensate the complainants. In Abdel Hadi Ali Radi and ors, a case involving the alleged torture of Sudanese IDPs by the police, the Commission found that the actions of the police were of such a serious nature that it attained the threshold of severity as to amount to torture. ${ }^{57}$

There has been flagrant disregard for the right to dignity of gay people in Nigeria. They are regularly harassed, tortured and publicly shamed. Michael Ighodaro is just one of the many victims of homophobic attacks. Michael told his story in a 2017 interview with a reporter from the Independent Newspapers UK. ${ }^{58} \mathrm{He}$ had been attacked by anti-gay vigilantes while waiting for a taxi outside his friend's home in the city of Abuja. This attack was predicated on his being featured in an article about an AIDS conference he had attended and facilitated in 2012. On that fateful day, Michael's attackers beat him blue-black and burnt his house and property. Worse still, he chose not to seek proper medical treatment, as he did not want anyone to know the cause of the attack.

The sad story of Olumide Olubunmi Akinnifesi is another which reflects the horrors that gay people go through in Nigeria. Akinnifesi was attacked in broad daylight by a mob in Ondo State, South West Nigeria in February 2016 for being gay. ${ }^{59}$ Sadly, he succumbed to his injuries the following day, and to date his attackers have not been brought to book. His case will be reviewed in further detail below.

In its 2016 publication 'Tell Me Where I Can Be Safe' - The Impact of Nigeria's Same Sex Marriage (Prohibition) Act, Human Rights Watch (HRW) ${ }^{60}$ documented several cases of harassment and torture of gay people. HRW conducted both face-to-face and telephonic interviews with many victims. One of such victims was George who described the humiliation he and others were put through following their arrest at a gathering thus: ${ }^{61}$ 
... We were all squeezed into the van, sitting on each other's laps. Immediately when we arrived at Apata police station [Ibadan], the police told us to take our clothes off. We had only underwear - boxer shorts on. The police ... told us to stand in front of the condoms, and gave one of the guys a board written: '21 gay men suspected'. Pictures were taken, the police had called a commercial photographer to take the pictures, but this is normal practice in Nigeria.

Another gay man who was also a victim of police brutality told HRW a sordid tale of humiliation, degradation and extortion. Oscar and his friends were beaten up at the police station, forced to strip and photographed. Before their release, they were loaded onto the back of an open police jeep and paraded around the city. ${ }^{62}$

The Constitutional Court of South Africa weighed in on the right to dignity of gay people in National Coalition for Gay and Lesbian Equality v Min. of Justice and others, where it held that criminalization of same-sex relationships violates the right to dignity, ${ }^{63}$ and noted that the constitutional protection of human dignity required that the value and worth of all individuals as members of the society be acknowledged. ${ }^{64}$ In 2014, the African Commission adopted a resolution condemning all forms of violence based on sexual orientation, deeming them to be human rights violations, most especially the right to life and dignity as guaranteed under the Banjul Charter. ${ }^{65}$ The Commission also condemned the persecution of persons based on their sexual orientation or gender identity. ${ }^{66}$

\subsection{The right to equality and non-discrimination}

The provisions of the Same Sex Marriage (Prohibition) Act is in direct contradiction to the provisions of the Nigerian Constitution and other human right instruments on the right to equality and non-discrimination. Section 42 of Nigeria's Constitution protects the right to equal treatment and non-discrimination. Section 42(1)(a) states as follows:

A citizen of Nigeria of a particular community, ethnic group, place of origin, sex, religion or political opinion shall not, by reason only that he is such a person

(a) Be subjected...to disabilities or restrictions to which citizens of Nigeria of other communities, ethnic groups, places of origin, sex, religion or political opinions are not made subject;

The above section does not expressly prohibit discrimination based on sexual orientation, like the South African Constitution does. Nigeria has however ratified the Banjul Charter, ${ }^{67}$ article 2 of which prohibits discrimination on several grounds. In its General Comment 20 on non-discrimination in the 
enjoyment of rights which are found in the ICESCR, the Committee on ESCR has held that these grounds include HIV status and sexual orientation.

It is suggested that Nigeria update its constitution to reflect the right to nondiscrimination based on sexual orientation. Section 9(3) and (4) of the South African Constitution - which is the non-discrimination provision - can be used as a guide in this regard. Section 9(3) of the South African Constitution provides:

The state may not unfairly discriminate directly or indirectly against anyone on one or more grounds, including race, gender, sex, pregnancy, marital status, ethnic or social origin, colour, sexual orientation, age, disability, religion, conscience, belief, culture, language and birth.

Section 9(3) is all encompassing. By expressly including sexual orientation in its provision on non-discrimination, South Africa sends out a clear statement on its position on the individual's right to their sexuality.

A change can be effected in the Nigerian Constitution by inserting the term 'sexual orientation' as one of the grounds listed in section 42(1). An example would be:

A citizen of Nigeria of a particular community, ethnic group, place of origin, sex, sexual orientation, religion or political opinion shall not, by reason only that he is such a person ...

Yet still, if the idea of expressly providing for the protection of people's fundamental rights with regards to sexual orientation is too inconceivable, Nigeria could borrow a leaf from the wordings of Article 2 of the Banjul Charter which includes the phrase 'or other status'. As reiterated by Murray and Viljoen, the inclusion of 'such as' and other status clearly shows that the list in article 2 is not exhaustive. ${ }^{68}$ This phrase has been stated to include sexual orientation. ${ }^{69}$ Taking such action will be in line with the directive of the African Commission in Resolution 275 that all States enact and apply appropriate laws prohibiting and punishing all forms of violence, including violence against sexual minorities, and that of the UN Committee on Economic, Social and Cultural Rights (Committee on ESCR) in General Comment 22 to the effect that to realize the right to sexual and reproductive health, states must first address laws, institutional arrangements and social practices which prevent individuals from effectively enjoying their sexual and reproductive health. ${ }^{70}$ As noted by the Committee, the right to sexual and reproductive health is indivisible from and interdependent with other rights, ${ }^{71}$ hence it must be provided for.

The all-encompassing phrase 'or other status' mentioned above could be applied in redrafting section 42(1). Section 42(1)(a) would then read like this:

A citizen of Nigeria of a particular community, ethnic group, Place of origin, sex, religion, political opinion or other status shall not by reason only that he is such a person be subjected ... to disabilities or restrictions .... 
This way, the fundamental rights of sexual minorities to equality and non-discrimination could be guaranteed by the Nigerian Constitution without assaulting the sensibilities of core traditional, moral or religious anti-gay adherents i.e. the rights of homosexuals to non-discrimination can be preserved without the words 'sexual orientation' being expressly incorporated into the Constitution. This is one of the ways that the elusive 'middle ground' could be achieved in Nigeria. For this to be achievable though, same-sex relationships first have to be decriminalized. It is important to stress that this is by no means a call to outrightly legalize same-sex relationships. Rather, it is a way of reaching a compromise between both extremes.

In addition to Article 2, Articles 3, 18 and 19 of the Banjul Charter provide for the right to equality and non-discrimination for all persons. Murray and Viljoen are of the opinion that the use of the inclusive phrases 'such as' and 'other status' in article 2 suggests that the drafters foresaw and indeed left room for an expansion of grounds under the article. ${ }^{72}$ They also put forward another interesting argument that 'sex' as used in article 2 of the Banjul Charter could be understood to include sexual orientation as well, but were quick to concede that such an expansive definition could militate against the more common understanding of the term 'sex'. ${ }^{73}$ Be that as it may, the position of the Commission on the right to equality and non-discrimination is clear.

Article 28 also imposes a duty on the individual to respect others without discrimination and to promote, safeguard and reinforce mutual respect and tolerance of all others. In the same vein, articles 1 and 2 of the Universal Declaration in upholding the right to equality and non-discrimination, reiterate that all human beings are born free and equal in dignity and rights. Article 7 of the Universal Declaration provides further for equality before the law and equal protection without any discrimination. Likewise, Articles 2, 3 and 26 of the ICCPR also guarantee the right to equality and non-discrimination.

Resolution 275 strongly condemned the persistence of discrimination and violence against sexual minorities, noting the failure of law enforcement agencies and states generally to address these issues. It has also been lauded for addressing the worsening incidence of discrimination and attacks on sexual minorities and activists and for negating the pervading notion that homosexuality is 'un-African'. ${ }^{74}$ In its Concluding Observations to Nigeria, the Commission condemned Nigeria's Same Sex Marriage (Prohibition) Act for its potential to engender violence against sexual minorities in the country, and to drive underground this group which is particularly vulnerable to HIV/ AIDS. ${ }^{75}$

In Young $v$ Australia, ${ }^{76}$ where the applicant had brought a complaint before the Human Rights Committee with regards to Australia's veterans' entitlements law wherein homosexual veterans were not entitled to the same pension as other veterans, the Committee found Australia to be in violation of Article 26 (which guaranteed the right to equality and non-discrimination). 


\subsection{The right to health}

The right to health is another fundamental right which criminalization of samesex relationships continues to undermine. Criminalization leads to discrimination and stigmatization, driving sexual minorities underground and making it difficult for them to access HIV prevention programmes or treatment, with devastating consequences. ${ }^{77}$

Article 25(1) of the Universal Declaration provides that 'everyone has the right to a standard of living adequate for the health and well-being of himself and of his family including ... medical care and other social services...'. Likewise, article 16(1) of the Banjul Charter guarantees the right for every individual to enjoy the best attainable state of physical and mental health, while Article 16(2) enjoins state parties to take necessary measures to protect the health of their citizens and to ensure that they receive medical attention when needed.

The Human Rights Committee has noted the connection between criminalization of homosexuality and the high prevalence of HIV/AIDS among homosexuals. ${ }^{78}$ As noted in its Concluding Observations to Nigeria above, criminalizing homosexuality drives the very people who are most vulnerable to HIV/AIDs underground, making it even more difficult to effectively tackle the pandemic. ${ }^{79}$ Gay men and other men who have sex with men have been recognized as one of the three major groups driving up the country's HIV/ AIDS numbers, with an HIV prevalence of $23 \%{ }^{80}$ A study on the impact of the Same Sex Marriage (Prohibition) Act on the healthcare-seeking behaviour of men who have sex with men in Abuja showed that the introduction of the Act negatively affected the healthcare-seeking behaviour of participants, due to the fear of discrimination and stigmatization. ${ }^{81}$

\subsection{Freedom of assembly}

This is another fundamental right that has been trampled upon by Nigeria's anti-gay law. Section 4(1) of the 2013 Act prohibits the registration of gay clubs, societies and organizations, while section 5(2) prescribes a jail term of ten years for anyone who registers, operates or participates in gay clubs, societies or organizations. This means sexual minorities are banned from forming associations to fight for their cause or advance their rights.

Shockingly, the Act goes further to impose liability on individuals who administer, witness or support the joining of same sex couples, or who support the 'registration, operation and sustenance of gay clubs, societies, organizations, processions or meetings' in Nigeria. ${ }^{82}$ Under the section, a jail term of ten years awaits such people on conviction. This is a mindless erosion of fundamental rights. In effect, families and friends who show support for gay people can be arrested and jailed for doing so. The same fate awaits licenced marriage officiators or religious leaders who choose not to discriminate by joining samesex couples. 
This freedom is guaranteed under section 40 of the 1999 Constitution. Section 40 entitles every person to 'assemble freely and associate with other persons', and to form or belong to any association for the protection of his interests. Thus, in terms of the section, gay people are entitled to form associations if they so wish to protect or advance their interests. To take this right away is to undermine their constitutional rights. The provisions of the Constitution are superior to any other law, and where there is a clash between the provisions of the Constitution and any other law, the Constitution will prevail. ${ }^{83}$

In addition to the Nigerian Constitution, the freedom of association and assembly is also guaranteed under Article 20(1) of the Universal Declaration, Articles 21 and 22 of ICCPR and Articles 10 and 11 of the Banjul Charter. Nigeria's stance under the 2013 Act is incompatible with its very own Constitution as well as its obligations as a state party to the above human rights instruments. In its Concluding Observations on Nigeria's 5th periodic Report on the implementation of the African Charter, ${ }^{84}$ the Commission called on Nigeria to review its Same Sex Marriage (Prohibition) Act, put an end to discrimination against sexual minorities, ensure the protection of their rights, ${ }^{85}$ and put in place measures to ensure freedom of expression. ${ }^{86}$

\section{Case studies from Nigeria}

Several examples abound of Nigerians who have suffered injustice for no other reason than being gay. Two of such cases will be considered briefly under this heading.

\subsection{Olumide Olubunmi Akinnifesi}

One of the most heartrending of all is that of Olumide Olubunmi Akinnifesi, who was viciously attacked by a mob in Ondo State on 17 February 2016, and who died as a result of that attack. ${ }^{87}$ Olumide was allegedly caught pants down with another man. Badly beaten and left for dead, he died the following day from internal bleeding. Fearing for his life, Olumide's alleged lover went into hiding. There were reports of harassment, and vandalism experienced by the families of the two men, and of people leaving offensive comments on Olumide's Facebook page. Even in death, Olumide was targeted by the antigay brigade.

\subsection{Michael Ighodaro}

Michael's story has been briefly discussed above. ${ }^{88}$ In a sit-down with The Independent Newspapers, Michael detailed how he was kicked out of his family home at the age of 17 , dropped out of school and forced to survive on the streets, for no other reason than because he was gay. He was attacked and severely injured by unknown assailants after his identity was compromised in 
Nigeria, and his house and property burnt. He was forced to flee the country and seek asylum in the United States.

These are just two of the many gay men who have experienced the full force of the homophobic wrath of Nigerians. Some like Michael, have lived to tell their stories. Sadly, others like Olumide have not been so lucky. The introduction of the 2013 Act further exacerbated the problem. In its 2016 publication discussed above, Human Rights Watch documented several instances of persecution experienced by gay people in Nigeria. No individual should be treated in the manner in which Nigeria's sexual minorities are being treated. The 2013 Act would seem to have put the seal of approval on their degradation and dehumanization.

\section{Lessons in tolerance - The Father Paul Kelly example.}

It has previously been argued that in the absence of an immediate acceptance of same-sex relationships, Nigeria as a country can shift ground to the extent that same-sex relationships are decriminalized, and fundamental rights of gay people in the country are not being violated. ${ }^{89}$

There is no better guidance on the possibility of finding a middle ground in the clash between religion and gay rights than the story of Father Paul Kelly. Father Paul is an Australian Catholic priest who gained national popularity for his role in the movement to abolish the homosexual advance defence (also known as the 'gay panic' defence or the partial defence) in Queensland..$^{90}$ The bill to remove the gay panic defence was passed on 20 March 2017.

The background story was that following an altercation on 3 July 2008 in Maryborough, Queensland, Wayne Ruks, an alleged gay man had been beaten and left to die by two men on the grounds of St Mary's Catholic Church. ${ }^{91}$ The attack had been caught on the church's CCTV cameras. At their trial, the men alluded to the homosexual advance defence to show provocation in terms of section 304 of the Queensland Criminal Code, thereby getting manslaughter convictions as opposed to murder. The partial defence of provocation found in section 304 reduces criminal responsibility for murder to manslaughter, and had created a loophole whereby people accused of murder could claim provocation due to an unwanted sexual advance. ${ }^{92}$ This defence was used for the first time in Australia in $R v$ Murley, ${ }^{93}$ and had been controversially entrenched in Green $v$ the Queen where the court had found, on appeal, that sexual advances of a non-violent nature were sufficient to establish provocation. ${ }^{94}$

A month after the attack on Ruks, another man, Stephen Ward, who was a hitchhiker was also bashed to death and his body dumped close to Maryborough. ${ }^{95}$ Ward's attacker also relied on the 'gay panic' defence, claiming that Ward had made a sexual advance at him. ${ }^{96}$ At the time of these two murders, the defence had been abolished in all jurisdictions in Australia, except Queensland and South Australia.

To Father Paul, these two incidents occurring so close to each other, signified a call to action. He then created a Change.org petition, which gained 
almost 290,000 signatures. ${ }^{97}$ On why he took up the campaign to change the law, Father Paul said: ${ }^{98}$

The more I thought about it, I thought, this didn't make any sense. It got me fired up. I realised that this really was a terrible loophole and should be closed.

Father Paul has been celebrated for the role he has played in changing the law, ${ }^{99}$ even being referred to as an LGBTI hero. ${ }^{100}$ Drawing from some of the teachings of Pope John Paul II, the priest has however said that stopping the homosexual advance defence 'is the gospel'. In his words 'this is real Christian teaching. They make it about homophobia when I'm trying to protect human dignity'. ${ }^{101}$ The priest acknowledged that his fight to put an end to the gay panic defence could be confused with fighting for gay rights, and has clarified that he remained aligned to the church's view on same-sex marriage. ${ }^{102}$ For Father Paul, the aim ultimately was to put an end to laws that tolerated violence against particular groups. ${ }^{103}$

It is remarkable that no religious leader in Nigeria has spoken out against the unending attacks on homosexuals in the country or tried to call their followers to order. Rather, they have been vocal in condemning sexual minorities, fuelling the raging homophobia in the country. Nigeria can learn a lot from Father Paul Kelly with regard to showing respect, compassion and tolerance for the causes of gay people. He has shown that it is possible to accept and understand others whose orientation or beliefs are different from the norm without outrightly supporting their orientation or beliefs.

It is submitted that the journey to changing attitudes towards sexual minorities begins with trying to understand them and their struggles. The words of His Lordship, Justice Ackerman in the National Coalition for Gay and Lesbian Equality case $\mathrm{e}^{104}$ to the effect that "To understand "the other" one must try as far as is humanly possible, to place oneself in the position of "the other" are of great significance to this discussion.

\section{Conclusion and recommendations}

This chapter has discussed Nigeria's Same Sex Marriage Prohibition Act 2013 in detail, and has examined how the Act, and Nigeria's other anti-gay laws encroach on the fundamental rights of gay people in Nigeria. It has shown how religious and cultural influences have shaped the demonization of samesex relationships in Nigeria.

The chapter has also proposed ways in which a compromise can be reached between the two extremes i.e. respecting the rights of sexual minorities without necessarily legalizing same-sex relationships. Although this could be considered as taking baby steps by the liberal world, it would be considered a major victory for gay activists and the gay community in Nigeria. 
To show that a compromise is possible in the midst of cultural, moral or religious sentiments, the chapter has discussed the inspirational story of Rev. Father Paul Kelly as a lesson in tolerance in spite of opposing beliefs. Following in the priest's footsteps in this regard will change the perception of homosexuality in Nigeria.

\section{Notes}

1 Cap C38, Laws of the Federation 2004.

2 These are Bauchi, Borno, Gombe, Jigawa, Kaduna, Kano, Katsina, Kebbi, Niger, Sokoto, Yobe and Zamfara.

3 e.g. sec 130 Zamfara State Shariah Penal Code Law.

4 Sec 129 of the Kano State Shariah Penal Code Law and section 131 of the Zamfara State Shariah Penal Code Law.

5 Sec 134 of the Bauchi State Shariah Penal Code Law.

6 Sec 132 of the Kebbi State Shariah Penal Code Law.

7 AT Adebanjo 'Culture, morality and the law: Nigeria's anti-gay law in perspective' (2015) 15(4) International Journal of Discrimination and the Law 256.

8 The Pew Research Centre 'The global divide on homosexuality' 2013 www.pewglobal. org/files/2013/06/Pew-Global-Attitudes-Homosexuality-Report-FINAL-JUNE-42013.pdf (accessed 27 October 2018).

$9 \mathrm{~J}$ Mujuzi 'Discrimination against homosexuals in Malawi: Lessons from recent developments' (2011) 11(3) International Journal of Discrimination and the Law 150.

10 (n 9).

11 'Homosexuality “poisoning” Nigerian society - Primate' Vanguard Newspapers (Lagos) 4 September 2018 https://www.vanguardngr.com/2018/09/homosexuality-poisoningnigerian-society-primate/ (accessed 13 October 2018).

12 BBC News 'Obasanjo backs bishops over gays' 27 October 2004 http://news.bbc.co.uk /2/hi/africa/3955145.stm (accessed 3 November 2018).

13 Adebanjo (n 8) 259.

14 H Baxter 'Dworkin's “One-System” conception of law and morality' (2010) 90 Boston University Law Review 858.

15 W Udobang “"The exorcism was over in 15 minutes but nothing changed" - LGBT life in Nigeria' The Guardian (New South Wales) 21 February 2017 https://www.theguardian.com/global-development-professionals-network/2017/feb/21/from-exorcism-toacceptance-lgbt-life-in-nigeria (accessed 3 November 2018).

16 Apart from the 2014 Act, the Ugandan Constitution of 1995 (as amended in 2005 to include a provision expressly criminalizing same-sex marriage) and the Ugandan Penal Code also criminalize same-sex relationships.

17 Oloka-Onyango \& Others v Attorney General, Uganda Constitutional Petition No 08 of 2014, 6 .

18 Sec 153 of the Penal Code Act of Malawi. Malawi however suspended its anti-gay laws in November 2012.

19 Sec 162 of the Kenyan Penal Code.

$20 \mathrm{Sec} 9(3)$ of the South African Constitution decriminalizes homosexuality by including 'sexual orientation' as one of the grounds for equality/non-discrimination.

21 UN OHCHR 'UN human rights chief denounces new anti-homosexuality law in Nigeria' 14 January 2014 https://www.ohchr.org/FR/newsEvents/Pages/DisplayNews .aspx?NewsID $=14169 \mathrm{amp} ; \mathrm{LangID}=\mathrm{E}$

22 Sec 7.

23 'Same-sex marriage, civil unions and domestic partnerships in South Africa: Critical reflections on an ongoing Saga' (2007) South African Law Journal 815. 
$24 \operatorname{Sec} 1(1)(b)$

$25 \operatorname{Sec} 2(2)$.

$26 \operatorname{Sec} 4(1)$.

$27 \operatorname{Sec} 5(2)$.

$28 \operatorname{Secs} 4(2) \& 5(2)$.

29 F Onuah, Reuters 'Nigerian leader signs anti-gay law, drawing US fire' 13 January 2014 http://www.reuters.com/article/2014/01/13/us-nigeria-gay-idUSBREA0C10820 140113 (accessed 4 November 2018).

30 A Nossiter 'Nigeria Tries to 'Sanitize' itself of Gays' The New York Times (New York) 8 February 2014 https://www.nytimes.com/2014/02/09/world/africa/nigeria-uses-lawand-whip-to-sanitize-gays.html (accessed 3 November 2018).

31 As above.

32 P De Vos 'A judicial revolution? The court-led achievement of same-sex marriage in South Africa' (2008) 4(2) Utrecht Law Review 173-174.

33 United Nations OHCHR 'Born free and equal: Sexual orientation and gender identity in international human rights law' (2012) New York E Geneva 7.

34 'Human Rights, Sexual Orientation and Gender Identity' A/HRC/RES/17/19 adopted at the 17th session of the Human Rights Council on 17 June 2011.

35 The Constitution of the Federal Republic of Nigeria 1999.

36 Art 12 Universal Declaration.

37 Art 17 ICCPR.

38 Human Rights Committee Communication No. 488/1992 (Toonen v Australia).

39 (Application no. 10581/83) European Court of Human Rights, 26 October 1988.

40 Para 1.

41 Paras 2.1-3.1.

42 Para 8.4.

43 Para 8.6.

44 Para 6.5.

45 Para 8.5.

46 Paras 9-11.

47 (Application nos 29381/09 and 32684/09) European Court of Human Rights, 7 November 2013.

48 Resolution 275 entitled 'Resolution on Protection against Violence and other Human RightsViolations against Persons on the basis of their real or imputed Sexual Orientation or Gender Identity'.

49 Arts $2,3,4 \& 5$.

50 AHRLR 153 (ACHPR 2003).

51 Communication 368/09.

52 Para 1.

53 Para 2.

54 Paras 5, 30.

55 Paras $30 \& 32$.

56 Para 37.

57 Paras 73-77.

58 This is discussed further in 5.2 below (Gander (n 89)).

59 W Odunsi 'TIERS condemns murder of Akinnifesi Olubunmi over alleged homosexualism' Daily Post (Lagos) 15 March 2016 http://dailypost.ng/2016/03/15/tierscondemns-murder-of-akinnifesi-olubunmi-over-alleged-homosexualism/ (accessed 13 October 2018).

60 Human Rights Watch “"Tell Me Where I can be safe" - The impact of Nigeria's Same Sex Marriage (Prohibition) Act' (2016) 37 https://www.hrw.org/sites/default/files/ report_pdf/nigeria1016_web.pdf (accessed 7 October 2018).

61 As above 35.

62 As above 35 . 


\section{Adetoun T Adebanjo}

63 CCT 11/98, Paras 26-28; [1999] (1) SA 6 (CC).

64 Para 28.

65 Resolution 275 on protection against Violence and other human Rights Violations against Persons on the basis of their real or imputed Sexual Orientation or Gender Identity adopted at the 55th Ordinary Session of the African Commission on Human and Peoples' Rights in Luanda, Angola, 28 April to 12 May 2014.

66 As above.

67 Nigeria ratified the Banjul Charter through the African Charter on Human and Peoples Rights (Ratification and Enforcement) Act 2004.

68 R Murray \& FViljoen 'Towards a non-discrimination on the basis of sexual orientation: The normative basis and procedural possibilities before the African Commission on Human and Peoples' Rights and the African Union (2007) 29 Human Rights Quarterly 86 at 91.

69 The Committee on ESCR General Comment 20 on non-discrimination in the enjoyment of rights as contained in the ICESCR.

70 CESCR General Comment 22 (2016) on the right to sexual and reproductive health (article 12 of the International Covenant on Economic, Social and Cultural Rights) E/C.12/GC/22 3.

71 As above 3 .

72 Murray \& Viljoen (n 69) 91.

73 As above 92.

74 International Service for Human Rights (ISHR) 'African Commission adopts landmark resolution on LGBT rights' 22 May 2014 https://www.ishr.ch/news/african-commission-adopts-landmark-resolution-lgbt-rights (accessed 27 November 2018).

75 Concluding Observations to Nigeria and Recommendations on the 5th Periodic Report of the Federal Republic of Nigeria on the Implementation of the African Charter on Human and Peoples' Rights (2011-2014) at 13, adopted at the 57th Ordinary Session $4-18$ November 2015 in Banjul, Gambia.

76 Human Rights Committee communication No. 941/2000 (Young v Australia).

77 Adebanjo (n 8) 266.

78 Para 9, Human Rights Committee Concluding Observation on Kenya CCPR/C/ $\mathrm{KEN} / \mathrm{CO} / 3$ adopted at its 105th session, 9-27 July 2012.

79 (n 76) 13.

80 Avert 'HIV and AIDS in Nigeria' https://www.avert.org/professionals/hiv-aroundworld/sub-saharan-africa/nigeria (accessed 20 April 2020) The other two groups are sex workers (14.4\%) and people who inject drugs (3.4\%).

81 R Schwartz et al 'The immediate effect of the Same Sex Marriage Prohibition Act on stigma, discrimination and engagement on HIV prevention and treatment services in men who have sex with men in Nigeria: Analysis of prospective data from the trust cohort' Lancet HIV 2015 July 1; 2(7) e299-e306. doi:10.1016/S2352-3018(15)00078-8, 6-8.

$82 \operatorname{Sec} 5(3)$ of the Act.

$83 \operatorname{Sec} 1(1)$ \& (3) of the 1999 Constitution.

84 Adopted at its 57th Ordinary session $4-18$ November 2015 Banjul, Gambia.

85 Para 126.

86 Para 121.

87 Odunsi (n 60); 'Gay: Nigeria scores 98 percent to top list of nations with least tolerance' National Daily (Lagos) 2 May 2016 https://nationaldailyng.com/gay-nigeria-scores-98percent-to-top-list-of-nations-with-least-tolerance/ (accessed 4 November 2018).

88 K Gander 'Gay in Nigeria - The stark reality for lgbt people in the west frican country' The Independent (UK) 23 May 2017 https://www.independent.co.uk/life-style/lovesex/gay-nigeria-lgbt-reality-life-violence-west-africa-flee-micheal-ighodaro-us-abusehomophobia-a7741161.html (accessed 14 October 2018).

89 Adebanjo (n 8) 268. 
90 T Crockford 'Death in his church grounds put priest on path to change Qld law' Brisbane Times (Brisbane) 21 March 2017 https://www.brisbanetimes.com.au/national/queensland/death-in-his-church-grounds-put-priest-on-path-to-change-qld-law-20170321gv3dfx.html (accessed 18 October 2018).

91 FWhiting 'Unholy war' The Courier-Mail (Brisbane) https://www.couriermail.com.au/ extras/qweekend/fff/features/pdfs/342.pdf?nk=92473147893b050ca04cad3ab2dc42631550667493 (accessed 3 November 2018).

92 F Caldwell 'Gay panic laws Queensland: Father Paul Kelly on why he kept up the fight' Brisbane Times (Brisbane) 2 December 2016 (updated 3 December 2016) https://www. brisbanetimes.com.au/national/queensland/gay-panic-laws-queensland-father-paulkelly-on-why-he-kept-up-the-fight-20161202-gt31ky.html (accessed 3 November 2018).

93 Unreported, Supreme Court of Victoria, Teague J 28 May 1992.

94 (1997) 191 CLR 334.

95 Crockford (n 91).

96 As above.

97 As above.

98 Caldwell (n 93).

99 F Caldwell 'Gay panic laws pass Queensland Parliament. Removing partial defence' Brisbane Times (Brisbane) 21 March 2017 https://www.brisbanetimes.com.au/national /queensland/gay-panic-laws-pass-queensland-parliament-removing-partial-defence20170321-gv32j8.html (accessed 3 November 2018). Ted Sorensen, Member for Hervey Bay was quoted as saying 'I wonder if this legislation would be here if it wasn't for Father Paul Kelly'.zza.

100 S Sivasubramanian, Special Broadcasting Service 'Meet an LGBTI hero: A catholic priest who's making it his mission to abolish the gay panic defence' 6 June 2016 (updated 7 June 2016) https://www.sbs.com.au/topics/sexuality/article/2016/06/ 06/meet-lbgti-hero-catholic-priest-whos-making-it-his-mission-abolish-gay-panic (accessed 3 November 2018).

101 As above.

102 As above.

103 As above.

104 CCT 11/98 (n 64) para 22.

\section{References}

Abdel Hadi, Ali Radi and ors v Repubic of Sudan Communication 368/09

Adebanjo, AT 'Culture, morality and the law: Nigeria's anti-gay law in perspective' (2015) 15(4) International Journal of Discrimination and the Law 256

Avert 'HIV and AIDS in Nigeria' https://www.avert.org/professionals/hiv-around-world/ sub-saharan-africa/nigeria (accessed 20 April 2020)

Barnard, J \& De Vos, P 'Same-sex marriage, civil unions and domestic partnerships in South Africa: Critical reflections on an ongoing saga' (2007) 124(4) South African Law Journal 795

Baxter, H 'Dworkin's “One-system” conception of law and morality' (2010) 90 Boston University Law Review 857

BBC News 'Obasanjo backs Bishops over gays' 27 October 2004 http://news.bbc.co.uk/2 /hi/africa/3955145.stm (accessed 3 November 2018)

Caldwell, F 'Gay panic laws Queensland: Father Paul Kelly on why he kept up the fight' Brisbane Times (Brisbane) 2 December 2016 (updated 3 December 2016) https://www 
.brisbanetimes.com.au/national/queensland/gay-panic-laws-queensland-father-paul-kelly -on-why-he-kept-up-the-fight-20161202-gt31 ky.html (accessed 3 November 2018).

Caldwell, F 'Gay panic laws pass Queensland Parliament. Removing partial defence' Brisbane Times (Brisbane) 21 March 2017 https://www.brisbanetimes.com.au/national /queensland/gay-panic-laws-pass-queensland-parliament-removing-partial-defence -20170321-gv32j8.html (accessed 3 November 2018).

Committee on Economic Social and Cultural Rights General Comment 20 (2009) on nondiscrimination in economic, social and cultural rights (art. 2 para. 2 of the International Covenant on Economic Social and Cultural Rights) E/C.12/GC/20

Committee on Economic Social and Cultural Rights General Comment 22 (2016) on the right to sexual and reproductive health (article 12 of the International Covenant on Economic, Social and Cultural Rights) E/C.12/GC/22

Crockford, T 'Death in his church grounds put priest on path to change Qld law' Brisbane Times (Brisbane) 21 March 2017 https://www.brisbanetimes.com.au/national /queensland/death-in-his-church-grounds-put-priest-on-path-to-change-qld-law -20170321-gv3dfx.html (accessed 18 October 2018)

De Vos, P 'A judicial revolution? The court-led achievement of same-sex marriage in South Africa' (2008) 4(2) Utrecht Law Review 162

Gander K 'Gay in Nigeria - The stark reality for lgbt people in the west African country' The Independent (UK) 23 May 2017 https://www.independent.co.uk/life-style/love -sex/gay-nigeria-lgbt-reality-life-violence-west-africa-flee-micheal-ighodaro-us-abuse -homophobia-a7741161.html (accessed 14 October 2018)

Human Rights Watch "Tell Me Where I Can Be Safe" - The impact of Nigeria's same sex marriage (prohibition) act (2016) https://www.hrw.org/sites/default/files/report_pdf/ nigeria1016_web.pdf (accessed 14 October 2018)

International Service for Human Rights 'African Commission adopts landmark resolution on LGBT rights' (2014) https://www.ishr.ch/news/african-commission-adopts-landmark -resolution-lgbt-rights (accessed 27 November 2018).

Mujuzi, JD 'Discrimination against homosexuals in Malawi: Lessons from recent developments' (2011) 11(3) International Journal of Discrimination and the Law 150

Murray, R \& Viljoen, F 'Towards a non-discrimination on the basis of sexual orientation: The normative basis and procedural possibilities before the African Commission on human and peoples' rights and the African Union' (2007) 29 Human Rights Quarterly 86

Odunsi, W 'TIERS condemns murder of Akinnifesi Olubunmi over alleged homosexualism' Daily Post (Lagos) 15 March 2016 https://dailypost.ng/2016/03/15/tiers-condemns -murder-of-akinnifesi-olubunmi-over-alleged-homosexualism/ (accessed 13 October 2018)

Onuah, F Reuters 'Nigerian leader signs anti-gay law, drawing US fire' 13 January 2014 http://www.reuters.com/article/2014/01/13/us-nigeria-gay-idUSBREA0C1 0820140113 (accessed 4 November 2018)

The Pew Research Centre 'The global divide on homosexuality' (2013) www.pewglobal .org/files/2013/06/Pew-Global-Attitudes-Homosexuality-Report-FINAL-JUNE-4 -2013.pdf (accessed 27 October 2018).

Schwartz, R et al 'The immediate effect of the Same Sex Marriage Prohibition Act on stigma, discrimination and engagement on HIV prevention and treatment services in men who have sex with men in Nigeria: Analysis of prospective data from the trust cohort' (2015) 2(7) Lancet HIV e299-306

Sivasubramanian, S Special Broadcasting Service 'Meet an LGBTI hero: A catholic priest who's making it is mission to abolish the gay panic defence' 6 June 2016 (updated 
7 June 2016) https://www.sbs.com.au/topics/sexuality/article/2016/06/06/meet -lgbti-hero-catholic-priest-whos-making-it-his-mission-abolish-gay-panic (accessed 3 November 2018)

Udobang, W “"The exorcism was over in 15 minutes but nothing changed” - LGBT life in Nigeria' The Guardian (New South Wales) 21 February 2017 https://www.theguardian .com/global-development-professionals-network/2017/feb/21/from-exorcism-to -acceptance-lgbt-life-in-nigeria (accessed 3 November 2018)

The UN Human Rights Council 'Human rights, sexual orientation and gender identity' A/HRC/RES/17/19 adopted at the 17th session of the Human Rights Council on 17 June 2011

The UN Human Rights Council 'Protection against violence and discrimination based on sexual orientation and gender identity’ A/HRC/RES/32/2 adopted 30 June 2016.

UN OHCHR 'Born free and equal: Sexual orientation and gender identity in international human rights law' (2012) New York \& Geneva

UN OHCHR 'UN human rights chief denounces new anti-homosexuality law in Nigeria' 14 January 2014 https://www.ohchr.org/FR/newsEvents/Pages/DisplayNews.aspx ?NewsID=14169amp;LangID=E

Vanguard Newspapers Homosexuality "poisoning” Nigerian society - Primate' (Lagos) 4 September 2018 https://www.vanguardngr.com/2018/09/homosexuality-poisoning -nigerian-society-primate/ (accessed 13 October 2018).

Whiting, F 'Unholy war' The Courier-Mail (Brisbane) https://www.couriermail.com.au/ extras $/$ qweekend $/ \mathrm{fff} /$ features $/$ pdfs $/ 342$.pdf?nk $=92473147893 \mathrm{~b} 050 \mathrm{ca} 04 \mathrm{cad} 3 \mathrm{ab} 2 \mathrm{dc} 4263$ -1550667493 (accessed 3 November 2018). 